\title{
Quantification of Cibenzoline by Enzyme-Linked Immunosorbent Assay
}

\author{
Tetsuya SAITA, * Akira TokunAgA, Masayoshi Egoshi, \\ Hideaki TOKUSHIMA, and Hiroshi FUJITO \\ Department of Pharmacy, Saga University Hospital, 5-1-1 Nabeshima, \\ Saga City 849-8501, Japan
}

(Received February 20, 2007; Accepted March 20, 2007)

\begin{abstract}
We have developed an enzyme-linked immunosorbent assay (ELISA) suitable for routine monitoring of serum levels of cibenzoline. Anti-cibenzoline antibody was obtained by immunizing rabbits with cibenzoline conjugated with bovine serum albumin using $N$-(4-maleimidobutyryloxy) succinimide as a heterobifunctional coupling agent. An enzyme marker was prepared by coupling 2,2-diphenylethylamine with $\beta$-D-galactosidase using glutaraldehyde. The detection limit of cibenzoline by ELISA was approximately $640 \mathrm{pg} / \mathrm{ml}$ with $50-\mu 1$ samples. Cross-reactivity data showed that the antibody well recognizes both the diphenyl and cyclopropyl moieties, and is thus specific enough to the structure of cibenzoline. The values for the cibenzoline concentrations detected using this assay were comparable with those detected using HPLC. There was a good correlation between the values determined by the two methods. Moreover, ELISA was about 15 -fold more sensitive in detecting cibenzoline at lower concentrations. Using this assay, drug levels were easily measured in the serum of rabbits after oral administration of cibenzoline at a single dose of $3 \mathrm{mg} / \mathrm{kg}$.
\end{abstract}

Key words_ cibenzoline; enzyme-linked immunosorbent assay (ELISA) ; antiarrhythmic drug

\section{INTRODUCTION}

Cibenzoline, $( \pm)$-2-(2,2-diphenylcyclopropyl)-2imidazoline, is a potent class Ia (sodium channel blocker) antiarrhythmic drug. ${ }^{1)}$ It is a widely used antiarrhythmic drug that is useful in the treatment of both ventricular and supraventricular arrhythmias, and adverse effects due to this drug have been minor and infrequent; ${ }^{2,3)}$ however, there have been several reports of hypoglycemia, occasionally associated with excessive insulin secretion, in patients receiving cibenzoline, both at overdose and at therapeutic plasma concentrations. ${ }^{4-6)}$ It is eliminated primarily by renal excretion, with about $60 \%$ of an administered dose recovered in the urine as unchanged drug; ${ }^{7)}$ therefore, in patients with reduced renal function, side effects such as hypoglycemia have been reported. It is necessary to adjust the administration interval and dosage according to the renal function. ${ }^{5,6,8)}$ Dose adjustment based on therapeutic drug monitoring (TDM) was beneficial for patients treated with cibenzoline in order to prevent hypoglycemia. Previous TDM and pharmacokinetic studies of cibenzoline were undertaken using HPLC; ${ }^{9,10)}$ however, pretreatments such as extraction of samples are necessary and the procedure is

\footnotetext{
*e-mail: saita@cc.saga-u.ac.jp
}

complex. Thus, the development of a simple quantification method of cibenzoline is needed. Enzymelinked immunosorbent assay (ELISA) appeared to be a suitable analytical method for this purpose. ELISA is generally very sensitive and specific, and has advantages in simplicity, cost, safety, and capacity of processing a large number of samples. If a kit and automatic method are developed, it will be used in many facilities. Recently, we have developed several ELISAs for some antiarrhythmic drugs, each of which was sensitive and specific and useful for TDM and pharmacokinetic studies of the individual drugs. ${ }^{11-14)}$

We present here the first report of ELISA for cibenzoline. The present study reports the methodology for antibody production, the labeling of cibenzoline with $\beta$-D-galactosidase $(\beta$-Gal) to act as a tracer, the characterization of antibody specificity, and the technique developed for the measurement of cibenzoline by ELISA. The initial application of the assay to measure drug levels in rabbits demonstrates its usefulness for the assessment of basic pharmacokinetic distributions.

\section{MATERIALS AND METHODS}

Reagents Cibenzoline succinate, 4,5-dehydrocibenzoline and 4,4'-dimethylcibenzoline were supplied by Suntory Ltd. (Osaka, Japan) . $\beta$-D-Galactos- 
idase ( $\beta$-Gal; EC 3.2.1.23) from Escherichia coli and 4-methylumbelliferyl- $\beta$-D-galactopyranoside were obtained from Boehringer Mannheim (Mannheim, Germany ). $\quad N$ - (4-Maleimidobutyryloxy ) succinimide (GMBS) and $N$ - $(\varepsilon$-maleimidocaproyloxy) succinimide (EMCS) were purchased from Dojin Chemical Co. (Kumamoto, Japan). 3-Maleimidobenzoic acid $\mathrm{N}$-hydroxysuccinimide ester (MBS) was purchased from Aldrich Chem. Co. (St. Louis, MO, U.S.A.) . Acetylmercaptosuccinyl bovine serum albumin (AMS.BSA) was prepared by the method of Klotz and Heiney. ${ }^{15)}$

Preparation of the Immunogen for Cibenzoline Cibenzoline succinate $(10 \mathrm{mg}, 26 \mu \mathrm{mol})$ in $2 \mathrm{ml}$ of 0.2 M phosphate buffer ( $\mathrm{pH}$ 7.0), was mixed with GMBS $(3.7 \mathrm{mg}, 23 \mu \mathrm{mol}$ ) in $0.5 \mathrm{ml}$ of tetrahydrofuran (THF) and incubated for $1 \mathrm{~h}$ at room temperature with stirring. After removing THF by passing nitrogen through the reacted mixture, the resulting cibenzoline-GMBS was extracted with $4 \mathrm{ml}$ of ether. The ether solution was dried over anhydrous sodium sulfate and then in a vacuum. At the same time, AMS.BSA $(10 \mathrm{mg})$, containing 17 acetylmercaptosuccinyl groups per BSA molecule, in $0.2 \mathrm{ml}$ of $0.1 \mathrm{M}$ phosphate buffer ( $\mathrm{pH} 7.0$ ) was incubated in $50 \mu$ l of freshly prepared $0.5 \mathrm{M}$ hydroxyamine $(\mathrm{pH} 7.0)$ at $25^{\circ} \mathrm{C}$ for 10 min to remove the protecting acetyl group. The resulting mercaptosuccinyl BSA, was diluted with 1 $\mathrm{ml}$ of $0.1 \mathrm{M}$ phosphate buffer ( $\mathrm{pH} 7.0$ ) containing $3 \mathrm{M}$ urea, added immediately to cibenzoline-GMBS in 250 $\mu \mathrm{l}$ of THF and then incubated at $25^{\circ} \mathrm{C}$ for $1 \mathrm{~h}$ with vigorous stirring. The reaction mixture was dialyzed successively for $48 \mathrm{~h}$ against 50 and $1 \mathrm{~mm}$ phosphate buffer ( $\mathrm{pH}$ 7.0) and $\mathrm{H}_{2} \mathrm{O}$. The purified conjugate was lyophilized and used as an immunogen for ELISA. Using the 4,4-dithiodipyridine method to determine the thiol group, ${ }^{16)}$ the conjugate was estimated to contain about 10.0 molecules of cibenzoline per BSA molecule.

Preparation of Cibenzoline Antibody One milliliter of saline with $1 \mathrm{mg}$ cibenzoline-BSA conjugate was emulsified with an equal volume of Freund's complete adjuvant. Two white female rabbits were each given multiple subcutaneous injections over sites along both sides of their backs. Booster injections were then given three times at bi-weekly intervals, using one-half the amount of the dose of the first immunization. The rabbits were bled from an ear vein 10 weeks after immunization began. Sera $(10 \mathrm{ml})$ were separated by centrifugation and heated at $55^{\circ} \mathrm{C}$ for $30 \mathrm{~min}$. Fractions of $\mathrm{IgG}$ were extracted from the sera with $50 \%$ saturated ammonium sulfate and chromatographed on a column of DEAE-Sephacel $(2.1 \times$ $23 \mathrm{~cm}$ ) using $17.5 \mathrm{~mm}$ phosphate buffer ( $\mathrm{pH} \mathrm{6.8)} \mathrm{as}$ an eluant. The fraction passed through the column was lyophilized and used as anti-cibenzoline $\mathrm{IgG}$ for ELISA.

Preparation of Enzyme Labeling 2,2-Diphenylethylamine $(50 \mu \mathrm{g}, 0.25 \mathrm{nmol})$ in $200 \mu \mathrm{l}$ of $0.1 \mathrm{M}$ phosphate buffer ( $\mathrm{pH}$ 7.0) was incubated with $1 \mu \mathrm{l}$ of $25 \%$ glutaraldehyde for $30 \mathrm{~s}$ with stirring. To this mixture was added $\beta$-Gal $(156 \mu \mathrm{g}, 0.28 \mathrm{nmol})$ in $20 \mu \mathrm{l}$ of $0.1 \mathrm{M}$ phosphate buffer $(\mathrm{pH} 7.0)$ and the mixture was incubated for $1 \mathrm{~h}$ with slow stirring at $30^{\circ} \mathrm{C}$. The mixture was chromatographed on a column of Sepharose $6 \mathrm{~B}(2.0 \times 40 \mathrm{~cm})$ using $20 \mathrm{~mm}$ phosphate buffer ( $\mathrm{pH}$ 7.0) containing $0.1 \mathrm{M} \mathrm{NaCl}, 1 \mathrm{mM} \mathrm{MgCl}_{2}$, $0.1 \% \mathrm{BSA}$ and $0.1 \% \mathrm{NaN}_{3}$ (buffer $\mathrm{A}$ ) to remove the remaining small molecules. Four-milliliter fractions were collected, and fractions 15 to 17 , representing the main peak showing enzyme activity, were combined and used as a label in ELISA.

ELISA for Determination of Cibenzoline ELISA is based on the principle of competition between enzyme-labeled and unlabeled drugs for an immobilized antibody, followed by measurement of the marker enzyme activity of the immunocomplex bound to the solid phase. Briefly, the wells in microtiter plates (Nunc F Immunoplates I; Nunc, Reskilde, Denmark) were coated by loading $150 \mu \mathrm{l}$ of anti-cibenzoline IgG $(2.0 \mu \mathrm{g} / \mathrm{ml})$ in $10 \mathrm{~mm}$ Tris- $\mathrm{HCl}$ buffer $(\mathrm{pH} 8.5)$ containing $10 \mathrm{mM} \mathrm{NaCl}$ and $10 \mathrm{mM} \mathrm{NaN}_{3}$ and allowed to stand for $1 \mathrm{~h}$ at $37^{\circ} \mathrm{C}$. After the plates had been washed twice with $60 \mathrm{~mm}$ phosphate buffer $(\mathrm{pH} 7.4)$ containing $10 \mathrm{mM}$ ethylenediaminetetraacetate, $0.1 \%$ BSA and $0.1 \% \mathrm{NaN}_{3}$ (buffer B), they were incubated with $200 \mu$ l of $10 \mathrm{~mm}$ Tris- $\mathrm{HCl}$ buffer (pH 8.5) containing $10 \mathrm{mM} \mathrm{NaCl}$ and $10 \mathrm{mM} \mathrm{NaN}_{3}$ containing $2 \%$ BSA for $20 \mathrm{~min}$ at $37^{\circ} \mathrm{C}$ to prevent non-specific adsorption. The anti-cibenzoline IgG-coated wells were then filled with $50 \mu \mathrm{l}$ of either 10 -fold diluted serum from drug-treated rabbits, or standard normal rabbit serum samples diluted 1:10 with buffer B (containing various concentrations of cibenzoline), followed immediately by $50 \mu \mathrm{l}$ of the pooled cibenzoline- $\beta$-Gal conjugate (diluted $1: 200$ in buffer B for cibenzoline) . The wells were then incubated for $1 \mathrm{~h}$ at $37^{\circ} \mathrm{C}$ and once again washed thoroughly with buffer $\mathrm{B}$. 
The activity of the enzyme conjugate bound to each well was then measured by the addition of $125 \mu \mathrm{l}$ of $0.1 \mathrm{mM}$ 4-methylumbelliferyl- $\beta$-D-galactopyranoside in buffer A, followed by incubation of the wells at 37 ${ }^{\circ} \mathrm{C}$ for $60 \mathrm{~min}$. The enzyme reaction was stopped by the addition of $75 \mu \mathrm{l}$ of $0.5 \mathrm{M}$ glycine- $\mathrm{NaOH}$ buffer ( $\mathrm{pH}$ 10.3) to each well, and the resulting 4methylumbelliferone was measured by spectrofluorometry at wavelengths of $355 \mathrm{~nm}$ for excitation and $460 \mathrm{~nm}$ for emission using a fluorescence microplate reader (Fluoroskan Ascent, Labsystems, Helsinki, Finland).

HPLC Method The HPLC system consisted of a Shimadzu Model LC-10AT liquid chromatograph equipped with a spectrophotometric detector SPD$10 \mathrm{AV}$ and a $5 \times 100 \mathrm{~mm}$ Radial-pak cartridge $5 \mathrm{CN}$ $(10 \mu \mathrm{m})$ column (Waters, Milford, MA, USA). The column was eluted with acetonitrile and $50 \mathrm{mM}$ potassium dihydrogen phosphate $(50: 50, \mathrm{v} / \mathrm{v})$ at a flow rate of $1.0 \mathrm{ml} / \mathrm{min}$, and the eluate was monitored at $214 \mathrm{~nm}$. The retention time and peak height were measured with a Shimadzu C-R7A chromatopac.

A $0.5 \mathrm{ml}$ volume of $1 \mathrm{M} \mathrm{NaOH}$ was added to $0.5 \mathrm{ml}$ of serum in a $15 \times 10 \mathrm{~mm}$ glass test tube. After the addition of $50 \mu \mathrm{l}$ of $4,4^{\prime}$-dimethylcibenzoline $(4 \mu \mathrm{g} / \mathrm{ml})$ as the internal standard, the mixture was extracted using $5 \mathrm{ml}$ of chloroform and shaken for $10 \mathrm{~min}$. After centrifugation for $5 \mathrm{~min}$ at $2270 \mathrm{~g}$, the organic layer (4 ml) was transferred to another glass tube. The extracted solvent was evaporated to dryness at $50^{\circ} \mathrm{C}$ under $\mathrm{N}_{2}$ gas. The residue was reconstituted in $50 \mu \mathrm{l}$ of acetonitrile, and $40 \mu \mathrm{l}$ was injected.

Pharmacokinetic Evaluation White female rabbits in the weight range of 3.5 to $4 \mathrm{~kg}$ were used in this study. Cibenzoline was orally administered at a dose of $3 \mathrm{mg} / \mathrm{kg}$ to the rabbits. The drug was dissolved in isotonic sodium chloride at concentrations of $3 \mathrm{mg} /$ ml. Blood samples were collected at $0.25,0.5,1,2,3$, 4, 6 and $8 \mathrm{~h}$ post-administration, and the serum was stored at $-20^{\circ} \mathrm{C}$ until assayed for cibenzoline concentration. The serum was diluted 10 -fold with buffer $B$ to obtain a cibenzoline concentration appropriate for measurement by ELISA.

\section{RESULTS AND DISCUSSION}

Cibenzoline was coupled to BSA with the intention of producing a specific anti-cibenzoline antibody using GMBS with two selective, functional succinimide and maleimide groups as a cross-linking agent. The
cibenzoline-BSA conjugate, about $10 \mathrm{~mol}$ of cibenzoline per mol of BSA, induced the formation of a specific antibody in each of the two rabbits immunized.

Cibenzoline- $\beta$-Gal conjugates (as a tracer) were also prepared using essentially the same procedure with EMCS and MBS structurally different from GMBS, to eliminate the production of antibody binding to the cross-linkage region of $\beta$-Gal. Using cibenzoline-EMCS- $\beta$-Gal or cibenzoline-MBS- $\beta$-Gal, ELISA for cibenzoline was developed; however, the sensitivities of the two newly developed ELISAs for cibenzoline were very low (data not shown). These findings suggest that anti-cibenzoline antibody recognizes at least an amide bond of GMBS-cibenzoline; therefore, cibenzoline- $\beta$-Gal conjugate was prepared using a partial structure of cibenzoline (2,2diphenylethylamine). In addition, the 2,2-diphenylethylamine was coupled with $\beta$-Gal using glutaraldehyde in consideration of the fact that it might avoid a cross-reaction with the antibody produced against the immunogen linkage group of GMBS. The conjugate thus obtained was stable in eluted buffer $(\mathrm{pH} 7.0)$ at $4^{\circ} \mathrm{C}$ at least six months without loss of enzyme activity and immunoreactivity.

The optimal quantities and optimal incubation time for each reaction were established. The dose-response standard curve of cibenzoline in the serum is shown in Fig. 1. The range of cibenzoline detection by ELISA was between $128 \mathrm{pg}$ and $2 \mu \mathrm{g} / \mathrm{ml}$ of cibenzoline. For practical purposes, the working range was arbitrarily set between 0.64 and $400 \mathrm{ng} / \mathrm{ml}$ based on the precision and accuracy findings for ELISA in serum (Table 1), which showed this ELISA to be a reproducible technique. Recoveries of five different cibenzoline levels ranging from $0.64 \mathrm{ng}$ to $400 \mathrm{ng} / \mathrm{ml}$ were satisfactory $(94.4$ to $105.9 \%, n=5)$. The relative standard deviation for intra- and interassays at five different cibenzoline levels between 0.64 to $400 \mathrm{ng} / \mathrm{ml}$ were 5.9 to $19.9 \%$ and 4.5 to $18.1 \%$ (each $n=5$ ), respectively. The detection limit of cibenzoline by ELISA is 0.64 $\mathrm{ng} / \mathrm{ml}$. The standard curve in the serum system was essentially the same as that in the buffer system (data not shown). Studies for dilution recovery were performed using 5-fold double dilutions of known concentrations of control sample, and the mean recovery was $95.5 \%$ (Table 2). The therapeutic range of cibenzoline was reported to be $200-800 \mathrm{ng} / \mathrm{ml} ;{ }^{17}$ ) therefore, this ELISA may be sensitive enough to 


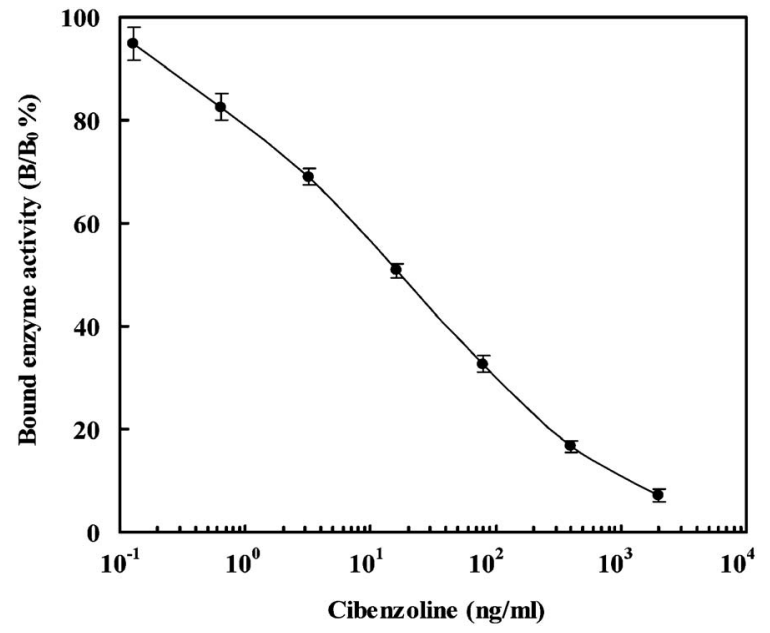

Fig. 1. Standard Curve for Cibenzoline in Human Serum

The curve shows the amount (\%) of bound enzyme activity for various doses of cibenzoline (B) as a ratio of that bound using cibenzoline- $\beta$-Gal alone $\left(B_{0}\right)$. Each point represents the mean \pm S.D. of 3 replicates.

Table 1. Precision and Recovery of ELISA for Cibenzoline in Human Serum

\begin{tabular}{lcccr}
\hline \hline \multirow{7}{*}{ Itraassay } & $\begin{array}{c}\text { Added } \\
(\mathrm{ng} / \mathrm{ml})\end{array}$ & $\begin{array}{c}\text { Estimated } \\
(\mathrm{ng} / \mathrm{ml})\end{array}$ & $\begin{array}{c}\text { Recovery } \\
(\%)\end{array}$ & $\begin{array}{c}\text { R.S.D. } \\
(\%)\end{array}$ \\
& 0.64 & $0.678 \pm 0.135$ & 105.9 & 19.9 \\
& 3.2 & $3.09 \pm 0.404$ & 96.6 & 13.1 \\
& 16.0 & $15.1 \pm 1.34$ & 94.4 & 8.9 \\
& 80.0 & $82.6 \pm 4.88$ & 103.3 & 5.9 \\
& 400.0 & $410.0 \pm 37.42$ & 102.5 & 9.1 \\
& 0.64 & $0.664 \pm 0.120$ & 103.8 & 18.1 \\
& 3.2 & $3.24 \pm 0.404$ & 101.3 & 12.5 \\
& 16.0 & $15.44 \pm 0.7$ & 96.5 & 4.5 \\
& 80.0 & $79.4 \pm 4.39$ & 99.3 & 5.5 \\
& 400.0 & $400.3 \pm 33.68$ & 100.1 & 8.4 \\
\hline
\end{tabular}

Values represent the mean \pm S.D. of 5 experiments.

Table 2. Cibenzoline Dilution Recovery Study

\begin{tabular}{ccc}
\hline \hline Dilution factor & Estimated $(\mathrm{ng} / \mathrm{ml})$ & Recovery $(\%)$ \\
\hline $1: 1$ & 392.0 & 100.0 \\
$1: 2$ & 180.0 & 91.8 \\
$1: 4$ & 98.3 & 100.3 \\
$1: 8$ & 45.0 & 91.8 \\
$1: 16$ & 22.0 & 89.8 \\
$1: 32$ & 12.7 & 103.7 \\
\hline
\end{tabular}

quantify cibenzoline for TDM.

Antibody specificity was determined by cross-reactivity with similar compounds, which was defined as the ratio of each compound to cibenzoline in the concentrations required for $50 \%$ inhibition of bound $\beta$ -
Table 3. Specificity of Anti-Cibenzoline IgG

4,5-Dehydrocibenzoline
2,4'-Dimethylcibenzoline

Gal activity. The anti-cibenzoline antibody showed $100 \%$ cross-reaction with the major cibenzoline metabolite, 4,5-dehydrocibenzoline, $28.0 \%$ with $4,4^{\prime}$ dimethylcibenzoline and $2.0 \%$ with 2,2-diphenylethylamine. No detectable cross-reaction, however, was found with benzophenone, cyclopropylbenzene and 2-methylimidazoline (Table 3). These findings suggest that the antibody well recognizes both the diphenyl and the cyclopropyl moieties, and is thus specific enough to the structure of cibenzoline.

This ELISA method was compared with an HPLC method for measuring human serum samples containing known amounts of standard cibenzoline. The HPLC technique analyzed 10 samples of various cibenzoline concentrations ranging from 0.1 to $2 \mu \mathrm{g} /$ $\mathrm{ml}$, showing a linear relationship between the peak height and the added cibenzoline dose. ELISA determination was carried out using these cibenzoline samples, properly diluted to adjust the drug concentration in the measurable range of ELISA. Figure 2 shows a linear correlation between the values determined by the two methods, providing the equation $\mathrm{Y}$ $=0.962 \mathrm{X}-0.02$, where $\mathrm{Y}$ is the concentration value 


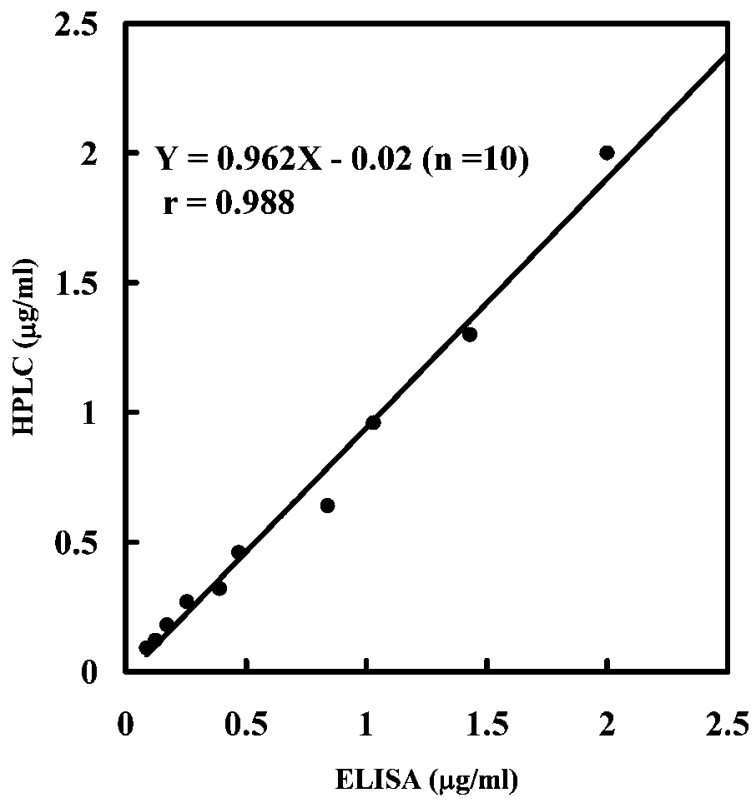

Fig. 2. Correlation of Cibenzoline Quantification by the Present ELISA and HPLC Methods

determined by HPLC analysis and X is that determined by ELISA; the correlation coefficient was 0.988 $(n=10)$. The ELISA sensitivity of $0.64 \mathrm{ng} / \mathrm{ml}$ as described above is about 15 -fold higher than that of HPLC. This finding also supports the high specificity of ELISA.

Figure 3 shows the time course of the serum concentrations of cibenzoline following its oral administration at a dose of $3 \mathrm{mg} / \mathrm{kg}$ to rabbits. Cibenzoline was rapidly absorbed, reaching a peak concentration in serum of $453.5 \mathrm{ng} / \mathrm{ml}$ (average in two rabbits) at 60 min after dosing, and then slowly decreased. As much as $60 \%$ of the oral dose appeared intact in the urine. ${ }^{7)}$ Metabolic studies in humans ${ }^{18)}$ and dogs ${ }^{19)}$ indicate that cibenzoline is the predominant excretion product in urine. Three metabolites were identified in human plasma or urine in quantifiable amounts: 4,5dehydrocibenzoline, $p$-hydroxycibenzoline, in both free and conjugated forms and $p$-hydroxybenzophenone. The only unconjugated metabolite in the plasma was 4,5-dehydrocibenzoline. The anti-cibenzoline antibody was found to cross-react $100 \%$ with 4,5 -dehydrocibenzoline; however, the concentration of this metabolite detected in human plasma was relatively low. The cross-reactivity of the other metabolites has not yet been confirmed and must be elucidated by further studies of the specificity of anti-cibenzoline antibody to these metabolites; however, the ELISA

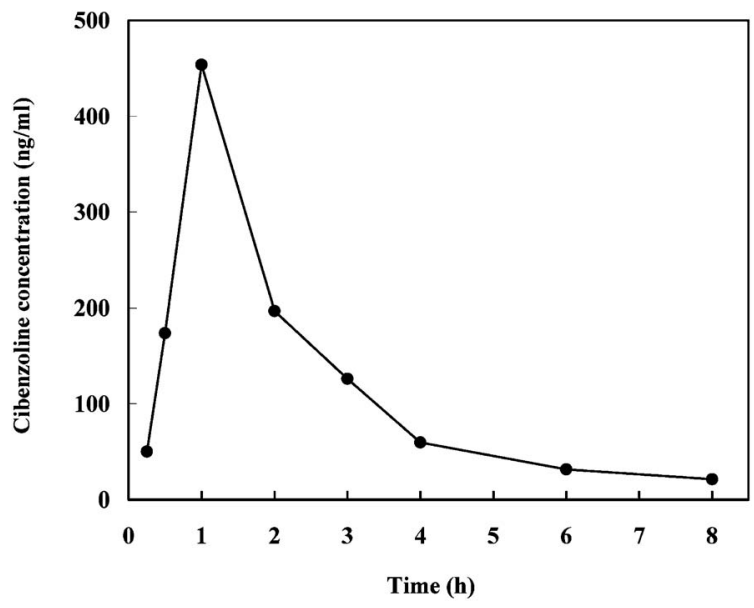

Fig. 3. Serum Cibenzoline Levels in Rabbits after a Single Oral Administration of Cibenzoline

Two rabbits, each weighing 3.5 to $4.0 \mathrm{~kg}$, were injected with $3 \mathrm{mg} / \mathrm{kg}$ cibenzoline. At each interval, blood was collected and the serum cibenzoline level was measured by ELISA.

procedure for cibenzoline reported here is sensitive, specific, reproducible, simple and adaptable to analyze a large number of samples. This ELISA will be a valuable tool in TDM and pharmacokinetic studies.

\section{REFERENCES}

1) Millar J. S., Vaughan Williams E. M., Br. $J$. Pharmacol., 75, 469-478 (1982).

2) Klein R. C., Horwitz L. D., Rushforth N., Am. J. Cardiol., 57, 592-597 (1986).

3) Kostis J. B., Davis D., Kluger J., Aogaichi K., Smith M., J. Cardiovasc. Pharmacol., 14, 8895 (1989).

4) Hilleman D. E., Mohiuddin S. M., Ahmed I. S., Dahl J. M., Drug Intell. Clin. Pharm., 21, 38-40 (1987).

5) Jeandel C., Preiss M. A., Pierson H., Penin F., Cuny G., Bannwarth B., Netter P., Lancet, 8596, 1232-1233 (1988).

6) Gachot B. A., Bezier M., Cherrier J., Daubeze J., Lancet, 8605, 280 (1988) .

7) Canal M., Flouvat B., Tremblay D., Dufour A., Eur. J. Pharmacol., 24, 509-515 (1983).

8) Kaneda K., Miyoshi N., Inoue T., Oribe Y. Saikawa T., J. Jpn. Soc. Dial. Ther., 27, 227231 (1994) (in Japanese).

9) Hackman M. R., Lee T. L., Brooks M. A., J. Chromatogr., 273, 347-356 (1983).

10) Kuhlkamp V., Schmid F., Ress K. M., Kramer B. K., Mayer F., Liebich H. M., Risler T., 
Seipel L., J. Chromatogr., 528, 267-273 (1990).

11) Saita T., Fujito H., Mori M., Biol. Pharm. Bull., 24, 1113-1116 (2001).

12) Saita T., Fujito H., Mori M., Biol. Pharm. Bull., 25, 954-958 (2002).

13) Saita T., Fujito H., Mori M., Biol. Pharm. Bull., 26, 761-765 (2003).

14) Saita T., Fujito H., Nakano Y., Mori M., Biol. Pharm. Bull., 27, 94-96 (2004) .

15) Klotz I., Heiney R. E., Arch. Biochem. Biophys., 96, 605-612 (1962).

16) Imagawa M., Hashida S., Ishikawa E.,
Sumiyoshi A., J. Appl. Biochem., 4, 400-410 (1982).

17) Ohtsuka M., Pharma Medica, 14, 155-165 (1996) (in Japanese).

18) Massarella J. W., Loh A. C., Williams T. H., Szuna A. J., Sandor D., Bressler R., Leinweber F. J., Drug Metab. Dispos., 14, 59-64 (1986).

19) Leinweber F. J., Szuna A. J., Loh A. C., Williams T. H., Sasso G. J., Bekersky I., Baggiolini E., Triscari J., Xenobiotica, 17, 14051414 (1987). 